\title{
Lost Seasonality and Overconsumption of Plants: Risking Oxalate Toxicity
}

\author{
Sally K. Norton, MPH \\ https://sallyknorton.com/
}

\section{Introduction}

World-wide, our contemporary health crisis involves the popularity of foods that cause both toxicity and nutrient deficiencies. Usually we think of sugar, trans-fats, and artificial ingredients as central culprits. Yet, one of the most potent toxins that people regularly ingest is naturally occurring oxalic acid and its oxalate salts. In the body, food-borne oxalates not only generate direct toxicity, they also deplete nutrients. This commentary argues for increased awareness of oxalates in foods and cautions against promotion of and regular use of foods high in oxalate.

\section{Oxalic Acid, Oxalates, and Calcium Oxalate Crystals}

Oxalic acid is a small 2-carbon molecule (formula $\mathrm{C}_{2} \mathrm{H}_{2} \mathrm{O}_{4}$ ) that readily donates protons thus forming oxalate ions $\left(\mathrm{C}_{2} \mathrm{O}_{4}{ }^{2-}\right)$ and oxalate salts. Being a chelating agent for metal cations, it forms soluble salts with the metal ions lithium (Li), sodium $(\mathrm{Na})$, and potassium $(\mathrm{K})$, and with ferrous salts. All other oxalates (notably calcium oxalate) are virtually insoluble at neutral or alkaline $\mathrm{pH}$.

Soluble oxalate and oxalate ions are universally toxic to mammals and easily move across membranes ${ }^{1-3}$. Purified forms have caused rapid deaths (typically accidental) since the early $1800 \mathrm{~s}^{4,5}$. Being hard to detect, even at doses that rapidly kill a person, oxalic acid was the poison of interest in the very first experimental toxicology study published in 1823 in England by Robert Christison and Charles Coindet ${ }^{6}$.

Free-form oxalate ions, soluble oxalate salts, insoluble oxalates, and mineralized calcium oxalate crystals occur naturally in plants, including food plants, in varying concentrations. Oxalate is also produced in the body in small quantities as a metabolic by-product. A group of rare genetic conditions, the primary hyperoxalurias $(\mathrm{PH})$, causes over-production of oxalate internally with deadly consequences ${ }^{7}$.

A diet with a preponderance of foods containing substantial oxalate has long been known to be dangerous, and sometimes deadly ${ }^{8}$. Oxalate in foods, including rhubarb $^{9-12}$, star fruit ${ }^{13-15}$, and sorre ${ }^{16}$ has been cited as the proximal cause of 
human deaths many times. Non-lethal oxalate toxicity is less recognized beyond the growing problem of kidney stones ${ }^{17}$.

\section{Toxic Mechanical Injury Due to Calcium Oxalate Crystals in Plants}

The insoluble calcium oxalate crystals in plants come in a wide array of sizes and shapes, including bundles of double pointed needles called raphides ${ }^{18}$. These calcium oxalate crystals are relatively stable minerals serving as durable microfossils of some archaeological interest, being found where other plant residues are no longer evident ${ }^{19}$.

Raphides are known to cause skin irritation, and oral and upper respiratory injury ${ }^{20}$. The non-food plant, Dieffenbachia, is a long-recognized and dramatic example. Excellent photographic illustration of oral and upper respiratory damage is offered in a recent report of a poisoning case requiring a 9-day hospitalization due to injuries sustained from brief exposure to a drop of Dieffenbachia $\operatorname{sap}^{21}$. Dieffenbachia possesses a system described as a defensive 'microscopic blowgun' whereby the tightly bundled raphides are forcefully ejected (assisted by turgor pressure of cell contents) for a distance of two to three cell lengths when the cells are disrupted. The "Needle Effect" of raphides has been demonstrated countless times, whereby traumatic injury results from the release of the raphides combined with the effects of proteases, soluble oxalate, and other chemical toxins carried on their surfaces and in their grooves in a defensive synergism ${ }^{22}$.

In many plants, including many that we eat, calcium oxalate crystals are present, although there is limited research on the specific forms and quantities of these crystals in foods. Hard and sharp-edged, oxalate crystals take many forms, in varying sizes, beyond the raphide ${ }^{23-26}$. They have the potential to inflict mechanical injury to $\operatorname{skin}^{20}$ teeth $^{27}$, and the mucosal linings of the alimentary canal ${ }^{28}$. These crystals may play an unrecognized role in the etiology of gut-associated illness. This type of localized oxalate toxicity involves mechanical abrasion and does not depend on absorption into the body.

\section{Oxalates are a likely contributor to many modern health problems}

Unlike the larger microcrystals of calcium oxalate, ionic, soluble and nano-crystal forms of oxalate are readily absorbed into the body ${ }^{29}$, however, a number of dynamic factors influence relative bio-availability ${ }^{30,31}$. A 2013 report of a study using radioisotope-labeled oxalate in rats by Susan Marengo, et al., demonstrated that "doses of oxalate typically considered unimportant have the potential to impact patient health" (p. 464) ( $^{32}$. These studies and others ${ }^{29,33,34}$ show that the typical amounts of oxalate in our diets can easily contribute to oxalate accumulation in non-renal tissues even though the kidneys are healthy and their handling capacity is not exceeded.

The formation of oxalate micro-crystals is especially common in human thyroid gland and breast tissue ${ }^{35,36}$. A study of 182 normal thyroids found that 
eighty-five percent of people over age 50 have calcium oxalate crystals in their thyroid gland ${ }^{37}$. This pathology has not been explained. Bio-accumulation in humans probably reflects the ubiquity of excessive oxalate in normal diets ${ }^{38-40}$. Oxalate has also been noted to cause pathological calcification ${ }^{41-43}$, weakened bones $^{44-46}$ and connective tissue ${ }^{47-49}$, tooth mobility ${ }^{50-54}$, and interfere with tissue healing ${ }^{55}$ and promote fibrosis ${ }^{41,56}$.

Regardless of accumulation in the body, exposure to ionic oxalate has deleterious effects, including loss of calcium and electrolyte imbalances ${ }^{57}$. Castellaro, et al. (2015) demonstrated that chronic exposure of ionic oxalate alters breast cells, transforming normal breast cells to tumor cells ${ }^{58}$. Many case studies also note oxalate-induced central nervous system dysfunction without evidence of micro-crystal accumulation in the brain ${ }^{59}$. Oxalate toxicity is associated with damage to the function and structure of nerves ${ }^{6,60-63}$.

Oxalate ions and nano-crystals are increasingly implicated as a cause or aggravator of a wide range of metabolic derangements associated with chronic health issues ${ }^{64-66}$. Dramatic increases in calcium-oxalate kidney stones, and functional problems with digestive health ${ }^{49}$, neurotoxicity ${ }^{59,61,67-69}$ (sleep, brain function), inflammation ${ }^{48,70-74}$ (chronic pain, autoimmunity, cellular stress, fatigue, arthritis), and connective tissue instability ${ }^{46,73,75,76}$ (osteoporosis, vulnerability to injury) are all consistent with increased oxalate toxicity ${ }^{43,77,78}$. Yet, these conditions (in tandem with the epidemic of insulin resistance and obesity) have led people to select foods purported to be healthier, many of which are high in oxalate.

\section{Healthy food promotion, "superfoods" and lost seasonality}

Modern dietary approaches, especially the "real food" movement (which includes ancestral health, Paleo, and vegetarian approaches) has placed great emphasis on the health benefits of vegetables, nuts, and spices. Without attention paid either to nutrient bioavailability or naturally occurring toxic substances, these approaches rank foods based on assumptions that all ingested nutrients are useful to the body, which is a dubious approach to healthy food selection ${ }^{79,80}$.

Worse still, many foods with the highest oxalate content have risen to the noble status of "superfoods", including: spinach, almonds (and most nuts), beets and swiss chard, blackberries ${ }^{81,82}$, potatoes and sweet potatoes, tea, chocolate, cinnamon, and turmeric ${ }^{83}$ (see Table 1 ). These items are increasingly available and celebrated as healthy ingredients, even in processed and convenience packaged foods. These high-oxalate foods are now promoted through a global food system in which seasons and even seasonal pricing have been erased in the retail marketplace.

The availability of high oxalate foods we see today is unprecedented. Fresh spinach and almond-based milk-alternative beverages, for example, are now in most markets everywhere, most every day of the year. An informal survey of the grocery market place (both in national chains and in local health food stores) easily 
demonstrates the proliferation of the availability of new formulations of staple foods and snack foods containing high oxalate ingredients.

This combination of "lost seasonality" and the growing popularity of neohealth food ingredients is especially dangerous with respect to oxalate consumption and the risk of toxicity. In this regard, the risk of harm from dietary oxalate may be more prevalent than at any other time in human history.

Academic papers suggest that consumption of oxalate typically falls into a narrow range of $100-150$ or $100-200 \mathrm{mg}$ daily ${ }^{84-87}$. These results tend to be based on small convenience samples. The authors do not describe dietary specifics, do not question the data or methods from which these estimates were derived, and do not discuss how these estimates may or may not be generalizable to other populations. These ranges also do not reflect the current food trends popularizing foods rich in oxalate. Estimating narrow ranges is unlikely to be useful in any case, as intake varies widely and we lack quality data supporting specific estimates.

Definitive, blanket statements about average oxalate intake belies both the variability and the idiosyncratic nature of food choices that can result in extremely high oxalate diets (either typically or periodically). The assumption of a steady oxalate intake level overlooks the dangers associated with the occasional ingestion of high-oxalate foods. Even a sporadic high oxalate meal (such as a spinach salad) can result in the growth of oxalate kidney stones ${ }^{88}$, and non-renal oxalate deposits as well ${ }^{32}$. Overlooking the impact of brief spikes in oxalate intake has masked the magnitude of the risks posed by dietary oxalate ${ }^{88}$.

\section{Foods Containing Oxalate and Alternative Foods}

Table 1 offers an incomplete, introductory listing of popular foods that are especially high in oxalate ${ }^{81,82,84,89-102}$. Legumes, grains, fruits, and several seasonings (including black pepper ${ }^{82}$ ) are omitted for simplicity, though many of those also contain relatively high concentrations.

Despite crude advice often given to kidney stone patients to avoid all greens, there are many leafy greens that have low concentrations of oxalates (see Table $2)^{82,91,92,94,94,94,95,100,102,103}$. There is no benefit to a blanket prohibition on greens, especially because this over-simplified myth obscures the oxalate content of other foods such as spices ${ }^{97}$, chocolate ${ }^{89,94}$, whole grains ${ }^{97}$, potatoes ${ }^{91,93,94}$, kiwi $^{82}$, figs ${ }^{97}$, and blackberries ${ }^{82}$. 
Table 1. High-Oxalate Foods Commonly Used by Health-Informed Public

\begin{tabular}{|l|l|l|}
\hline Vegetables & Nuts and Seeds & "Superfoods" \\
\hline Beets & Almonds & Carob \\
Okra & Cashews & Chocolate; Cocoa \\
Plantain & Chia & Cinnamon \\
Potato & Peanuts & Cumin \\
Spinach & Pine nuts & Black Tea \\
Swiss chard & Poppy seeds & Green Tea \\
Sweet Potato & Sesame & Turmeric \\
Rhubarb & & \\
\hline
\end{tabular}

Table 2. Low Oxalate Greens

Arugula
Bok Choy
Belgian Endive
Cabbage
Lettuce
Mâche (Corn Salad)
Mustard Greens
Watercress

\section{Modern Practices Increase Our Exposure and Susceptibility}

Though humans have encountered and eaten high-oxalate foods for millennia, consuming them in quantity on a daily basis threatens to overwhelm our body's ability to handle them without tissue damage, overt toxicity, and bioaccumulation. The continuous consumption we see today fails to offer time off when the body can expel accumulated oxalate, principally via the urine. The body may secondarily shunt oxalate to the colon especially when the kidneys can no longer handle the oxalate load and when the commensal bacterium Oxalobacter formigenes is present $^{104}$.

Ubiquitous overuse of antibiotics ${ }^{105}$, food additives (especially emulsifying agents that act like detergents in the gut, scrubbing away protective mucus ${ }^{106}$ ), overconsumption of oxalate itself ${ }^{107}$, and other factors (known and unknown) have dramatically altered our gut microbiome and caused chronic intestinal inflammation in many people. The resulting changes in bacterial species and endothelial health in the human colon may increase absorption of oxalate and diminish our ability to excrete oxalate ${ }^{108}$. And, the chronic intestinal inflammation allows for higher rates of oxalate absorption into the body, which occurs by simple diffusion ${ }^{109,110}$. Another modern assault to gut health, bariatric surgery, has created a new and growing class of people with special susceptibility to oxalates due also to increased absorption ${ }^{111-113}$. Gastrointestinal lipase-inhibiting weight-loss drugs, especially Orlistat, also increase oxalate absorption ${ }^{114}$.

Our kidneys naturally have an impressive but limited capacity to excrete oxalates. Modernity poses threats to our kidney health through the hazards of drugand toxin-induced kidney damage ${ }^{115}$, and the overconsumption of sugar-sweetened soda $^{116,117}$ and fructose ${ }^{118-120}$; sub-par intake of potassium ${ }^{121-123}$ and calcium ${ }^{124}$; and insulin resistance ${ }^{125}$ and the dietary and lifestyle conditions that lead up to it. Oxalate itself is a major source of kidney damage that makes it easier for oxalate to get stuck in the kidney causing a vicious cycle ${ }^{126-128}$. Renal damage, regardless of 
the cause, lowers the efficiency of oxalate excretion and increases the likelihood of both renal and non-renal tissue damage from oxalate ${ }^{129}$.

\section{Bioaccumulation of Oxalate}

One study using $50 \mathrm{gm}$ of plain chocolate containing $55 \mathrm{gm}$ of oxalate ${ }^{130}$ (about $65 \%$ soluble $^{94}$ ) demonstrated that an ordinary dose of dietary oxalate, although transient, can "trigger" a $235 \%$ increase in oxalate excretion, to levels found in $\mathrm{PH}$ cases. This level of exposure is enough to incite temporary renal "failure" and establish oxalate deposits in renal $^{34,131}$ and in non-renal tissues alike ${ }^{32,33}$. This occurs even when plasma oxalate values are within the normal range and kidney function is good. Oxalates are known to collect at sites of inflammation ${ }^{132}$ and injury ${ }^{133}$ where they delay healing or cause further damage. Attachment at sites of injured, inactive, stagnant tissue evades cellular clearance mechanisms, allowing minute deposits to grow and serve as sites of ongoing accumulation, owing to semicontinuous occurrence of oxalate in body fluids.

Yet, oxalate sequestered in tissues likely retains the potential to be released later (by liposomal digestion, in non-alkaline tissues) when oxalate consumption goes down ${ }^{134,135}$. But in today's food market, neither a "low-oxalate season" nor times of food scarcity have been seen in many decades. Under these conditions, cell damage may be inevitable and especially in connective tissues.

\section{Symptoms of Oxalate Toxicity}

Oxalates can trigger inflammasome reactions that may confuse our immune systems and lead to autoimmunity ${ }^{78,136,137}$. They impair bone health ${ }^{138,139}$ as well as neurological $^{68,140}$, cardiovascular $^{41-43}$, and kidney function ${ }^{12,141,142}$.

The symptoms of oxalate toxicity can be very hard to identify primarily because the patterns vary in idiosyncratic ways from person to person ${ }^{7}$. They are often subtle, typically affect multiple body systems, and often flare up unpredictably and irregularly_perhaps as the body tries to let go of them. These symptoms are common and non-specific (GI distress, headaches, joint and back pain) and can be vague (including generalized malaise, low energy, frequent urination). Because objective tests of urine ${ }^{141}$ and tissue biopsy ${ }^{37}$ are unreliable, oxalate-related symptoms go unrecognized as such. Despite several recent medical case reports that faulted the consumption of peanuts ${ }^{8,142,143}$, green juices ${ }^{8}$ and smoothies $^{144}$, tea ${ }^{145}$, nuts and nut butter ${ }^{146}$, cashews ${ }^{147}$, and a weight loss diet consisting of spinach, kale, berries, and nuts ${ }^{148}$ for kidney failure in patients, oxalates remain obscure compounds of no special concern in modern health care.

\section{Historical Diagnosis}

We didn't always ignore this problem. Oxalate-induced whole-body illness was a recognized, although debated, condition in the $19^{\text {th }}$ and early $20^{\text {th }}$ centuries, known to be associated with diet and manifesting with digestive, neurological, and 
rheumatic problems ${ }^{149}$. In the $5^{\text {th }}$ edition of his famous 1857 textbook, Urinary Deposits, Golding Bird stated “... we are told... that oxalate of lime is of constant occurrence, and of no importance. A remark to which too many sufferers from this diathesis can give a melancholy denial." — 5th ed., (1857), p. $217^{150}$

But, like the perpetual elusiveness of the remedy for kidney stones, associating non-renal oxalate toxicity with objective clinical tests of body fluids (especially urine) remained unsolvable. Thus, the idea of non-renal oxalate toxicity, especially when kidney function appears normal, was essentially dismissed. As a result, deeper investigations of case reports or direct experiments on humans are far too few and often flawed.

In the late 1800 s and early 1900 s, dietary intervention was recognized as an effective treatment for a constellation of symptoms associated with rhubarb season or with poor oxalate metabolism. The early knowledge has slipped into obscurity, awaiting rediscovery by a funding- and fad-driven research environment and a medical paradigm that in the early $20^{\text {th }}$ Century decisively decomposed the human body into isolated body parts and systems. In the nutrition sciences, especially in epidemiology, preconceived cultural notions dominate and limit the questions researchers are willing to investigate. For example, toxicology data on naturally occurring plant toxins is very limited. As toxicologist Gerrit Speijers puts it:

"Perhaps the hesitation to imply the safety aspects of inherent plant toxins in the agricultural research on plant breeding, fed by the fear that important and valuable plant foods would become a perceived health risk, has also contributed to the backlog in knowledge of the inherent plant toxins." - Speijers (1995), p. $224^{79}$.

\section{Side-Stepping the Trigger/Maintenance Processes with Diet}

Once the body is retaining oxalates, lowering oxalate intake consistently to the expected average intake of around 100-150 mg per day may not be enough to reverse the damage, although research in this area is lacking. Vermeulen's Trigger and Maintenance theory ${ }^{131}$ and many anecdotal reports (and the very definition of a low oxalate diet) indicate that intake must go below this "maintenance" exposure to a level that permits the destabilization and clearance of deposits and eventual tissue recovery. This trigger/maintenance response suggests that controlling and reversing oxalate toxicity in people who have become "accumulators" requires lowering oxalate levels in the diet to under $\sim 60$ milligrams a day. For reference, a half cup of cooked spinach contains several hundred milligrams of oxalate (330 $520 \mathrm{mg})^{82,90,94}$.

There are many therapeutic and preventive benefits of avoiding dietary oxalates, including improvements in kidney function ${ }^{87,88,146,151-154}$. In addition, both published and unpublished reports suggest benefits such as reversal of 
neurotoxicity (brain fog, cognition, behavioral and mood disorders, and sleep improvements ${ }^{155}$ ), recovery of connective tissue stability ${ }^{89,156}$ and reduced symptoms of autoimmunity ${ }^{136}$.

However, with improved kidney function, tissue stores of oxalate can be mobilized (as has been observed after kidney transplants in primary hyperoxaluria $(\mathrm{PH})$ patients $^{157,158}$ and in the symptoms reported by thousands of low oxalate dieters without $\mathrm{PH}^{155}$ ). Even when tissue clearance of oxalate from the body provokes on-going periodic elevated oxalate excretion, improved kidney function is evident ${ }^{153,154}$.

The safety of the oxalate release process depends, in part, on the rate of release not exceeding the body's alkaline buffering capacity and kidney tolerance. Even when within metabolic capacity, periodic elevated circulating oxalate is likely to cause temporary symptom "flare-ups" with the potential to damage kidneys, the vascular system and other tissues during "clean-out" phases. There is also some evidence among $\mathrm{PH}$ patients that events such as surgery/surgical recovery ${ }^{49}$, lithotripsy ${ }^{159}$, and giving birth ${ }^{160}$ may mobilize oxalate from previously quiescent internal deposits ${ }^{161,162}$. Similarly, acute oxalate nephropathy has followed non-renal organ transplantation in patients with cystic fibrosis. ${ }^{163}$

The reversal of oxalate accumulation in cases of dietary hyperoxaluria has never been formally monitored. Among PH patients, the time required for resolution of hyperoxaluria following liver and kidney transplantation varies widely. Tissues continue to release oxalate for a minimum of three years ${ }^{157}$ and may carry on for well beyond seven years ${ }^{162}$. Data is limited due to the small number of $\mathrm{PH}$ patients, poor survival rates, and lack of long-term follow-up testing. However, these lengthy release periods are consistent with reports from individuals who have systematically followed a long-term low-oxalate diet ${ }^{155}$.

Reactions to the low oxalate diet are varied, from simple symptom relief, to serious side-effects in some cases ${ }^{155}$. An abrupt shift from a high oxalate intake to a low oxalate intake may be ill-advised due to the potential for excessive mobilization $^{155}$.

\section{Awareness Lacking}

Biomedical researchers, clinicians, and the public health workforce have virtually no awareness of the threat of biological toxicity posed by over-exposure to oxalate. As a result, oxalate in plants (as well as other natural toxins) are overlooked as a potential problem associated with a number of popular foods. Ignorance of oxalate toxicity may pose an enormous, hidden, and growing threat to public health.

Unfortunately, neither dietary professionals nor the consuming public are aware of the presence or dangers of oxalates in familiar and trusted foods. Even lists of oxalate content from the USDA and major universities offer very incomplete data that is riddled with errors ${ }^{89,164}$. 
Encouragement of consumption of high-oxalate foods could lead to increased morbidity, not less as is claimed and desired. This is because the potential to ingest and absorb "trigger" doses and consistently eat "maintenance" doses can lead to a growing body burden of oxalate as well as constant exposure to ionic oxalate. The action we must take is to stop poisoning ourselves ${ }^{165}$. It makes no difference if the toxin is a man-made poison or one of nature's poisons. A single toxin interfering with the function of the connective tissue, immune system, nerves, glands, digestion and elimination deserves our attention ${ }^{80}$.

\section{Conclusion}

Despite the prevailing message that there is no upper safety limit for plant food consumption, not all vegetables and seeds are healthy and safe to eat on a regular basis, as toxicological studies and many case reports have proven. Sub-lethal exposure to oxalate contributes to disease, although we typically overlook the nonlethal effects and the non-renal effects ${ }^{166}$.

The basic logic of biology tells us that the two biggest drivers of illness are toxicity and deficiency. Regular and repeated exposure to a toxic substance is harmful. Plants are inherently toxic; even food plants retain varying degrees of toxicity. However, this notion is foreign to the general public and health professionals alike.

In today's bifurcated food world dominated by sugary, nutrient-poor convenience foods opposed by super-charged "health" foods featuring high-oxalate ingredients, the overall health outlook remains ominous. The promotion of high oxalate foods is likely to have the opposite of the intended effect. Rather than making us healthier, the superfood craze could be, not unlike the holy war against saturated fat, launching another public health calamity, as expensive and unpleasant as the current diabetes and obesity explosion. Those of us promoting healthy eating owe it to ourselves, and to those we hope to help, to get informed about oxalate toxicity, and to embrace dietary strategies that enable us to avoid and ultimately recover from it.

"From a practical point of view, it would be better to avoid oxalaterich foods [...], especially when other sources of green vegetables are available." - Hoover and Karunairatnam (1945) ${ }^{57}$ 


\section{References}

1. Crampton RF, Charlesworth FA. Occurrence of natural toxins in food. $\mathrm{Br}$ Med Bull 1975;31(3):209-213.

2. Moffatt RE. Renal oxalosis in the cat. Can Vet J Rev Vét Can 1977;18(12):351.

3. Waltner-Toews D, Meadows DH. Urolithiasis in a Herd of Beef Cattle Associated with Oxalate Ingestion. Can Vet J 1980;21(2):61-62.

4. Clendinning J. Observations on the History of Oxalic Acid as a Poison. Lond Med Surg J 1833;III:586-588.

5. Blyth AW. Poisons: their effects and detection: a manual for the use of analytical chemists and experts; with an introductory essay on the growth of modern toxicology. London: C. Griffin; 1884.

6. Christison R, Coindet C. An experimental inquiry on poisoning by oxalic acid. Edinb Med Surg J Exhib Concise View Latest Most Important Discov Med Surg Pharm 1823;

7. Lorenz EC, Michet CJ, Milliner DS, Lieske JC. Update on Oxalate Crystal Disease. Curr Rheumatol Rep 2013;15(7):340.

8. Getting JE, Gregoire JR, Phul A, Kasten MJ. Oxalate Nephropathy Due to 'Juicing': Case Report and Review. Am J Med 2013;126(9):768-772.

9. Tallqvist H, Vaananen I. Death of a child from oxalic acid poisoning due to eating rhubarb leaves. Ann Paediatr Fenn 1960;6:144-7.

10. Kalliala H, Kauste O. Ingestion of rhubarb leaves as cause of oxalic acid poisoning. Ann Paediatr Fenn 1964;10:228-231.

11. Robb H. Death from rhubarb leaves due to oxalic acid poisoning. $J$ Am Med Assoc 1919;73(8):627-628.

12. Sanz P, Reig R. Clinical and pathological findings in fatal plant oxalosis. A review. Am J Forensic Med Pathol 1992;13(4):342-345.

13. Chen CL, Fang HC, Chou KJ, Wang JS, Chung HM. Acute oxalate nephropathy after ingestion of star fruit. Am J Kidney Dis Off J Natl Kidney Found 2001;37(2):418-422. 
14. Neto MM, Costa JAC da, Garcia-Cairasco N, Netto JC, Nakagawa B, Dantas M. Intoxication by star fruit (Averrhoa carambola) in 32 uraemic patients: treatment and outcome. Nephrol Dial Transplant 2003;18(1):120-125.

15. Chang JM, Hwang SJ, Kuo HT, et al. Fatal outcome after ingestion of star fruit (Averrhoa carambola) in uremic patients. Am J Kidney Dis Off J Natl Kidney Found 2000;35(2):189-193.

16. Farre M, Xirgu J, Salgado A, Peracaula R, Reig R, Sanz P. Fatal oxalic acid poisoning from sorrel soup. The Lancet 1989;334(8678-8679):1524.

17. Marengo SR, Romani AMP. Oxalate in renal stone disease: the terminal metabolite that just won't go away. Nat Clin Pract Nephrol 2008;4(7):368377.

18. Prychid CJ, Jabaily RS, Rudall PJ. Cellular Ultrastructure and Crystal Development in Amorphophallus (Araceae). Ann Bot 2008;101(7):983-995.

19. Crowther A. Re-viewing raphides: Issues with the identification and interpretation of calcium oxalate crystals in microfossil assemblages [Internet]. In: Fairbairn AS, O'Connor S, Marwick B, editors. New Directions In Archaeological Science. Terra Austrailis 28, ANU E-Press; 2009 [cited 2015 Jul 31]. p. 105-118.Available from:

http://www.academia.edu/2561859/Reviewing_raphides_Issues_with_the_identification_and_interpretation_of_cal cium_oxalate_crystals_in_microfossil_assemblages

20. Salinas ML, Ogura T, Soffchi L. Irritant contact dermatitis caused by needlelike calcium oxalate crystals, raphides, in Agave tequilana among workers in tequila distilleries and agave plantations. Contact Dermatitis 2001;44(2):9496.

21. Altin G, Sanli A, Erdogan BA, Paksoy M, Aydin S, Altintoprak N. Severe destruction of the upper respiratory structures after brief exposure to a dieffenbachia plant. J Craniofac Surg 2013;24(3):e245-247.

22. Konno K, Inoue TA, Nakamura M. Synergistic defensive function of raphides and protease through the needle effect. PloS One 2014;9(3):e91341.

23. Ilarslan H, Palmer RG, Horner HT. Calcium Oxalate Crystals in Developing Seeds of Soybean. Ann Bot 2001;88(2):243-257. 
24. Lersten NR, Horner HT. Development of the calcium oxalate crystal macropattern in pomegranate (Punica granatum, Punicaceae). Vol 92 2005;92(12):1935-1941.

25. Webb MA. Cell-mediated crystallization of calcium oxalate in plants. Plant Cell 1999;11(4):751-761.

26. Franceschi V. Calcium oxalate in plants. Trends Plant Sci 2001;6(7):331.

27. Danielson DR, Reinhard KJ. Human dental microwear caused by calcium oxalate phytoliths in prehistoric diet of the lower Pecos region, Texas. Am J Phys Anthropol 1998;107(3):297-304.

28. McIntire MS, Guest JR, Porterfield JF. Philodendron--an infant death. $J$ Toxicol Clin Toxicol 1990;28(2):177-183.

29. Heaney RP, Weaver CM. Oxalate: effect on calcium absorbability. Am J Clin Nutr 1989;50(4):830-832.

30. Israr B, Frazier RA, Gordon MH. Effects of phytate and minerals on the bioavailability of oxalate from food. Food Chem 2013;141(3):1690-1693.

31. Massey LK. Food oxalate: factors affecting measurement, biological variation, and bioavailability. J Am Diet Assoc 2007;107(7):1191-1194; quiz 1195-1196.

32. Marengo S, Zeise B, Wilson C, MacLennan G, Romani AP. The triggermaintenance model of persistent mild to moderate hyperoxaluria induces oxalate accumulation in non-renal tissues. Urolithiasis 2013;41(6):455-466.

33. Blumenfrucht MJ, Cheeks C, Wedeen RP. Multiorgan crystal deposition following intravenous oxalate infusion in rat. J Urol 1986;135(6):12741279.

34. Holmes RP, Ambrosius WT, Assimos DG. Dietary oxalate loads and renal oxalate handling. J Urol 2005;174(3):943-947; discussion 947.

35. Wang Z, Tangella K, Balla A, Popescu G. Tissue refractive index as marker of disease. J Biomed Opt [Internet] 2011 [cited 2015 Jun 16];16(11).

Available from: http://www.ncbi.nlm.nih.gov/pmc/articles/PMC3223513/ 
36. Radi MJ. Calcium oxalate crystals in breast biopsies. An overlooked form of microcalcification associated with benign breast disease. Arch Pathol Lab Med 1989;113(12):1367-1369.

37. Katoh R, Suzuki K, Hemmi A, Kawaoi A. Nature and significance of calcium oxalate crystals in normal human thyroid gland. A clinicopathological and immunohistochemical study. Virchows Arch A Pathol Anat Histopathol 1993;422(4):301-306.

38. Glew RH, Sun Y, Horowitz BL, et al. Nephropathy in dietary hyperoxaluria: A potentially preventable acute or chronic kidney disease. World $J$ Nephrol 2014;3(4):122-142.

39. Siener R, Hönow R, Voss S, Seidler A, Hesse A. Oxalate content of cereals and cereal products. J Agric Food Chem 2006;54(8):3008-3011.

40. Chai W, Liebman M. Oxalate content of legumes, nuts, and grain-based flours. J Food Compos Anal 2005;18(7):723-729.

41. Salyer WR, Hutchins GM. Cardiac lesions in secondary oxalosis. Arch Intern Med 1974;134(2):250-252.

42. Fishbein GA, Micheletti RG, Currier JS, Singer E, Fishbein MC. Atherosclerotic Oxalosis in Coronary Arteries. Cardiovasc Pathol Off J Soc Cardiovasc Pathol 2008;17(2):117-123.

43. Shavit L, Girfoglio D, Vijay V, et al. Vascular calcification and bone mineral density in recurrent kidney stone formers. Clin J Am Soc Nephrol CJASN 2015;10(2):278-285.

44. Aydin NE, Usta U. Oxalate deposition in tissues. Nephrol Dial Transplant 2004;19(5):1323-1324.

45. Maldonado I, Prasad V, Reginato AJ. Oxalate crystal deposition disease. Curr Rheumatol Rep 2002;4(3):257-264.

46. Brancaccio D, Poggi A, Ciccarelli C, et al. Bone changes in end-stage oxalosis. AJR Am J Roentgenol 1981;136(5):935-939.

47. Fielder AR, Garner A, Chambers TL. Ophthalmic manifestations of primary oxalosis. Br J Ophthalmol 1980;64(10):782-788. 
48. Boogaerts MA, Hammerschmidt DE, Roelant C, Verwilghen RL, Jacob HS. Mechanisms of vascular damage in gout and oxalosis: crystal induced, granulocyte mediated, endothelial injury. Thromb Haemost 1983;50(2):576580.

49. Johnson J, Short A, Hutchison A, Parrott N, Roberts I. Small intestinal infarction: a fatal complication of systemic oxalosis. J Clin Pathol 2000;53(9):720-721.

50. Bimstein E, Wagner M, Nauman RK, Abrams RG, Shapira L. Root surface characteristics of primary teeth from children with prepubertal periodontitis. J Periodontol 1998;69(3):337-347.

51. Panis V, Tosios KI, Gagari E, Griffin TJ, Damoulis PD. Severe periodontitis in a patient with hyperoxaluria and oxalosis: a case report and review of the literature. J Periodontol 2010;81(10):1497-1504.

52. Lapointe HJ, Listrom R. Oral manifestations of oxalosis secondary to ileojejunal intestinal bypass. Oral Surg Oral Med Oral Pathol 1988;65(1):76-80.

53. Hedemark A, Bang G, Gammeltvedt AT, Anda S. Dental and jaw changes in primary hyperoxaluria. J Oral Pathol Med Off Publ Int Assoc Oral Pathol Am Acad Oral Pathol 1989;18(10):586-589.

54. Moskow BS. Periodontal manifestations of hyperoxaluria and oxalosis. $J$ Periodontol 1989;60(5):271-278.

55. Mehendale HM. Toxicodynamics of low level toxicant interactions of biological significance: inhibition of tissue repair. Toxicology 1995;105(23):251-266.

56. Khan SR. Reactive oxygen species, inflammation and calcium oxalate nephrolithiasis. Transl Androl Urol 2014;3(3):256-276.

57. Hoover AA, Karunairatnam NC. Oxalate content of some leafy green vegetables and its relation to oxaluria and calcium utilization. Biochem $J$ 1945;39(3):237.

58. Castellaro AM, Tonda A, Cejas HH, et al. Oxalate induces breast cancer. BMC Cancer 2015;15:761. 
59. Moorhead PJ, Cooper DJ, Timperley WR. Progressive peripheral neuropathy in patient with primary hyperoxaluria. Br Med J 1975;2(5966):312-313.

60. Samarneh MM, Shtaynberg N, Goldman M, Epstein E, Kleiner M, ElSayegh S. Severe oxalosis with systemic manifestations. J Clin Med Res 2012;4(1):56-60.

61. Blyth AW (and B Meredith, Blyth MW. Poisons : Their Effects and Detection. 4th ed. London, England: Charles Griffin and Company; 1906.

62. Tsai M-H, Chang W-N, Lui C-C, et al. Status epilepticus induced by star fruit intoxication in patients with chronic renal disease. Seizure - Eur J Epilepsy 2005;14(7):521-525.

63. Auxiliadora-Martins M, Alkmin Teixeira GC, Silva GS da, et al. Severe encephalopathy after ingestion of star fruit juice in a patient with chronic renal failure admitted to the intensive care unit. Heart Lung J Crit Care 2010;39(5):448-452.

64. Sun X-Y, Ouyang J-M, Zhu W-Y, Li Y-B, Gan Q-Z. Size-dependent toxicity and interactions of calcium oxalate dihydrate crystals on Vero renal epithelial cells. J Mater Chem B 2015;3(9):1864-1878.

65. Mulay SR, Desai J, Kumar SV, et al. Cytotoxicity of crystals involves RIPK3-MLKL-mediated necroptosis. Nat Commun 2016;7:10274.

66. Elferink JG. The mechanism of calcium oxalate crystal-induced haemolysis of human erythrocytes. Br J Exp Pathol 1987;68(4):551-557.

67. Lewis LD, Smith BW, Mamourian AC. Delayed sequelae after acute overdoses or poisonings: cranial neuropathy related to ethylene glycol ingestion. Clin Pharmacol Ther 1997;61(6):692-699.

68. Chen C-L, Chou K-J, Wang J-S, Yeh J-H, Fang H-C, Chung H-M. Neurotoxic effects of carambola in rats: the role of oxalate. $J$ Formos Med Assoc Taiwan Yi Zhi 2002;101(5):337-341.

69. Rahman SS, Kadakia S, Balsam L, Rubinstein S. Autonomic dysfunction as a delayed sequelae of acute ethylene glycol ingestion : a case report and review of the literature. J Med Toxicol Off J Am Coll Med Toxicol 2012;8(2):124-129. 
70. Adams ND, Carrera GF, Johnson RP, Latorraca R, Lemann J. Calciumoxalate-crystal-induced bone disease. Am J Kidney Dis Off J Natl Kidney Found 1982;1(5):294-299.

71. Coral A, Holsbeeck M van, Hegg C. Case report 599: Secondary oxalosis complicating chronic renal failure (oxalate gout). Skeletal Radiol 1990;19(2):147-149.

72. Marconi V, Mofid MZ, McCall C, Eckman I, Nousari HC. Primary hyperoxaluria: report of a patient with livedo reticularis and digital infarcts. J Am Acad Dermatol 2002;46(2 Suppl Case Reports):S16-18.

73. Brady HR, Fay WP, Meema HE, Rabinovich S, Rapoport A, Oreopoulos DG. Oxalate bone disease--an emerging form of renal osteodystrophy. Int J Artif Organs 1989;12(11):715-719.

74. Symmans PJ, Brady K, Keen CE. Calcium oxalate crystal deposition in epithelioid histiocytes of granulomatous lymphadenitis: analysis by light and electronmicroscopy. Histopathology 1995;27(5):423-429.

75. Reginato AJ. Calcium Oxalate and Other Crystals or Particles Associated with Arthritis. In: Koopman WJ, editor. Arthritis and Allied Conditions. Philadelphia, PA [etc.]: Lippincott Williams \& Wilkins; 2001.

76. Rubenstein MC, Martinelli PT, Bayer-Garner IB, Klebuc MJ, Curry JL, Hsu S. Persistent cutaneous manifestations of hyperoxaluria after combined hepatorenal transplantation. Dermatol Online J 2004;10(1).

77. Ermer T, Eckardt KU, Aronson PS, Knauf F. Oxalate, inflammasome, and progression of kidney disease. Curr Opin Nephrol Hypertens 2016;25(4):363-71.

78. Mulay SR, Kulkarni OP, Rupanagudi KV, et al. Calcium oxalate crystals induce renal inflammation by NLRP3-mediated IL-1 $\beta$ secretion. $J$ Clin Invest 2013;123(1):236-246.

79. Speijers GJ. Toxicological data needed for safety evaluation and regulation on inherent plant toxins. Nat Toxins 1995;3(4):222-226; discussion 242.

80. Singh PP, Kothari LK, Sharma DC, Saxena SN. Nutritional value of foods in relation to their oxalic acid content. Am J Clin Nutr 1972;25(11):1147-1152. 
81. The Low Oxalate Diet Addendum Fall 2008- Numerical Values Table. VP Found Newsl 2008;(31):7-11.

82. The Low Oxalate Diet Addendum Fall 2012 - Numerical Values Table. VP Found Newsl 2013;(38).

83. Tang M, Larson-Meyer DE, Liebman M. Effect of cinnamon and turmeric on urinary oxalate excretion, plasma lipids, and plasma glucose in healthy subjects. Am J Clin Nutr 2008;87(5):1262-1267.

84. Holmes RP, Kennedy M. Estimation of the oxalate content of foods and daily oxalate intake. Kidney Int 2000;57(4):1662-1667.

85. Siener R, Ebert D, Nicolay C, Hesse A. Dietary risk factors for hyperoxaluria in calcium oxalate stone formers. Kidney Int 2003;63(3):1037-1043.

86. Holmes RP, Knight J, Assimos DG. Origin of Urinary Oxalate. American Institute of Physics; 2007. p. 176-182.

87. Zimmermann DJ, Hesse A, Unruh GE von. Influence of a high-oxalate diet on intestinal oxalate absorption. World J Urol 2005;23(5):324-329.

88. Holmes RP, Knight J, Assimos DG. Lowering urinary oxalate excretion to decrease calcium oxalate stone disease. Urolithiasis 2016;44(1):27-32.

89. Yount J, Gottlieb A. The low oxalate cookbook, book two. Graham, NC: Vulvar Pain Foundation; 2005.

90. The Low Oxalate Diet Addendum Aug. 2004- Numerical Values Table. VP Found Newsl 2004;(24):9.

91. The Low Oxalate Diet Addendum Summer 2010 - Numerical Values Table. VP Found Newsl 2010;(34).

92. The Low Oxalate Diet Addendum Winter 2010 - Numerical Values Table. VP Found Newsl 2010;(33):18-23.

93. The Low Oxalate Diet Addendum Spring 2011 - Numerical Values Table. VP Found Newsl 2011;(35):14-17.

94. The Low Oxalate Diet Addendum Summer 2012 - Numerical Values Table. VP Found Newsl 2012;(37):6-9, 19-25. 
95. The Low Oxalate Diet Addendum Fall 2014 - Numerical Values Table. VP Found Newsl 2014;(41):16-17.

96. The Low Oxalate Diet Addendum Spring 2014 - Numerical Values Table. VP Found Newsl 2014;(40):18-20.

97. The Low Oxalate Diet Addendum Fall 2011 - Numerical Values Table. VP Found Newsl 2011;(36):17-20.

98. The Low Oxalate Diet Addendum Fall 2007- Numerical Values Table. VP Found Newsl 2007;(29):8-10.

99. The Low Oxalate Diet Addendum Fall 2013 - Numerical Values Table. VP Found Newsl 2013;(39):16-17.

100. The Low Oxalate Diet Addendum Spring 2008- Numerical Values Table. VP Found Newsl 2008;(30):19-22.

101. Hönow R, Hesse A. Comparison of extraction methods for the determination of soluble and total oxalate in foods by HPLC-enzyme-reactor. Food Chem 2002;78(4):511-521.

102. Autism Oxalate Project Food Testing Results, (University of Wyoming). Trying Low Oxalates. 2011;

103. The Low Oxalate Diet Addendum Summer 2009 - Numerical Values Table. VP Found Newsl 2009;(32):8-11.

104. Hatch M, Cornelius J, Allison M, Sidhu H, Peck A, Freel RW. Oxalobacter sp. reduces urinary oxalate excretion by promoting enteric oxalate secretion. Kidney Int 2006;69(4):691-698.

105. Kelly JP, Curhan GC, Cave DR, Anderson TE, Kaufman DW. Factors related to colonization with Oxalobacter formigenes in U.S. adults. $J$ Endourol 2011;25(4):673-679.

106. Chassaing B, Koren O, Goodrich JK, et al. Dietary emulsifiers impact the mouse gut microbiota promoting colitis and metabolic syndrome. Nature [Internet] 2015 [cited 2015 Mar 2]; Available from:

http://www.nature.com/doifinder/10.1038/nature14232

107. Suryavanshi MV, Bhute SS, Jadhav SD, Bhatia MS, Gune RP, Shouche YS. Hyperoxaluria leads to dysbiosis and drives selective enrichment of oxalate 
metabolizing bacterial species in recurrent kidney stone endures. Sci Rep 2016;6:34712.

108. Sidhu H, Schmidt ME, Cornelius JG, et al. Direct correlation between hyperoxaluria/oxalate stone disease and the absence of the gastrointestinal tract-dwelling bacterium Oxalobacter formigenes: possible prevention by gut recolonization or enzyme replacement therapy. J Am Soc Nephrol JASN 1999;10 Suppl 14:S334-40.

109. Dobbins JW. Oxalate and intestinal disease. J Clin Gastroenterol 1979;1(2):165-169.

110. Canos HJ, Hogg GA, Jeffery JR. Oxalate nephropathy due to gastrointestinal disorders. Can Med Assoc J 1981;124(6):729-733.

111. Gkentzis A, Kimuli M, Cartledge J, Traxer O, Biyani CS. Urolithiasis in inflammatory bowel disease and bariatric surgery. World J Nephrol 2016;5(6):538-546.

112. Lieske JC, Mehta RA, Milliner DS, Rule AD, Bergstralh EJ, Sarr MG. Kidney stones are common after bariatric surgery. Kidney Int 2014;

113. Earnest DL, Johnson G, Williams HE, Admirand WH. Hyperoxaluria in Patients with Ileal Resection: An Abnormality in Dietary Oxalate Absorption. Gastroenterology 1974;66(6):1114-1122.

114. Humayun Y, Ball KC, Lewin JR, Lerant AA, Fülöp T. Acute oxalate nephropathy associated with orlistat. J Nephropathol 2016;5(2):79-83.

115. Choudhury D, Ahmed Z. Drug-associated renal dysfunction and injury. Nat Clin Pract Nephrol 2006;2(2):80-91.

116. Cheungpasitporn W, Thongprayoon C, O’Corragain OA, Edmonds PJ, Kittanamongkolchai W, Erickson SB. Associations of sugar-sweetened and artificially sweetened soda with chronic kidney disease: a systematic review and meta-analysis. Nephrol Carlton Vic 2014;19(12):791-797.

117. Bray GA, Popkin BM. Dietary Sugar and Body Weight: Have We Reached a Crisis in the Epidemic of Obesity and Diabetes? Health Be Damned! Pour on the Sugar. Diabetes Care 2014;37(4):950-956. 
118. Cirillo P, Gersch MS, Mu W, et al. Ketohexokinase-dependent metabolism of fructose induces proinflammatory mediators in proximal tubular cells. $J$ Am Soc Nephrol JASN 2009;20(3):545-553.

119. Johnson RJ, Sanchez-Lozada LG, Nakagawa T. The Effect of Fructose on Renal Biology and Disease. J Am Soc Nephrol 2010;21(12):2036-2039.

120. Gersch MS, Mu W, Cirillo P, et al. Fructose, but not dextrose, accelerates the progression of chronic kidney disease. Am J Physiol-Ren Physiol 2007;293(4):F1256-F1261.

121. 2015-2020 Dietary Guidelines for Americans [Internet]. 8th ed. U.S. Department of Health and Human Services and U.S. Department of Agriculture.; 2015 [cited 2017 Dec 30]. Available from: https://health.gov/dietaryguidelines/2015/guidelines/

122. McNally MA, Pyzik PL, Rubenstein JE, Hamdy RF, Kossoff EH. Empiric use of potassium citrate reduces kidney-stone incidence with the ketogenic diet. Pediatrics 2009;124(2):e300-304.

123. Ferraro PM, Mandel EI, Curhan GC, Gambaro G, Taylor EN. Dietary Protein and Potassium, Diet-Dependent Net Acid Load, and Risk of Incident Kidney Stones. Clin J Am Soc Nephrol 2016;11(10):1834-1844.

124. Hoppe B, Leumann E, Unruh G von, Laube N, Hesse A. Diagnostic and therapeutic approaches in patients with secondary hyperoxaluria. Front Biosci J Virtual Libr 2003;8:e437-443.

125. De Cosmo S, Menzaghi C, Prudente S, Trischitta V. Role of insulin resistance in kidney dysfunction: insights into the mechanism and epidemiological evidence. Nephrol Dial Transplant Off Publ Eur Dial Transpl Assoc - Eur Ren Assoc 2013;28(1):29-36.

126. Thamilselvan V, Menon M, Thamilselvan S. Oxalate at physiological urine concentrations induces oxidative injury in renal epithelial cells: effect of $\alpha$ tocopherol and ascorbic acid. BJU Int 2014;114(1):140-150.

127. Vervaet BA, Verhulst A, D’Haese PC, Broe MED. Nephrocalcinosis: new insights into mechanisms and consequences. Nephrol Dial Transplant 2009;24(7):2030-2035.

128. Mulay SR, Evan A, Anders H-J. Molecular mechanisms of crystal-related kidney inflammation and injury. Implications for cholesterol embolism, 
crystalline nephropathies and kidney stone disease. Nephrol Dial Transplant Off Publ Eur Dial Transpl Assoc - Eur Ren Assoc 2014;29(3):507-514.

129. Gambaro G, Valente ML, Zanetti E, et al. Mild tubular damage induces calcium oxalate crystalluria in a model of subtle hyperoxaluria: Evidence that a second hit is necessary for renal lithogenesis. J Am Soc Nephrol JASN 2006;17(8):2213-2219.

130. Balcke P, Zazgornik J, Sunder-Plassmann G, et al. Transient hyperoxaluria after ingestion of chocolate as a high risk factor for calcium oxalate calculi. Nephron 1989;51(1):32-34.

131. Vermeulen C, Lyon E, Ellis J, Borden T. The renal papilla and calculogenesis. J Urol 1967;97:573-582.

132. Park J-A, Lee YJ, Lee JW, et al. Evaluation of [(89)Zr]-Oxalate as a PET Tracer in Inflammation, Tumor, and Rheumatoid Arthritis Models. Mol Pharm 2016;13(7):2571-2577.

133. Garner A. Retinal oxalosis. Br J Ophthalmol 1974;58(6):613-619.

134. Lieske JC, Norris R, Swift H, Toback FG. Adhesion, internalization and metabolism of calcium oxalate monohydrate crystals by renal epithelial cells. Kidney Int 1997;52(5):1291-1301.

135. Doyle WF, Brahman HD, Burgess JH. The nature of yellow-brown bodies in peritoneal lymph nodes. Arch Pathol 1973;96(5):320-326.

136. Susan Costen Owens. Celiac and the Inflammasome: Reasons for the Relevance of Oxalate and other Triggers. J Gluten Sensit Summer 2016 Issue [Internet] 2016;15(3). Available from: http://www.celiac.com/articles/24438/1/Celiac-and-the-InflammasomeReasons-for-the-Relevance-of-Oxalate-and-other-Triggers /Page1.html

137. Darisipudi MN, Knauf F. An update on the role of the inflammasomes in the pathogenesis of kidney diseases. Pediatr Nephrol Berl Ger 2016;31(4):535544.

138. Knight RQ, Taddonio RF, Smith FB, Weseley S, Pecker HM. Oxalosis: cause of degenerative spinal stenosis. A case report and review of the literature. Orthopedics 1988;11(6):955-958. 
139. Nakazawa R, Hamaguchi K, Hosaka E, Shishido H, Yokoyama T. Cutaneous oxalate deposition in a hemodialysis patient. Am J Kidney Dis Off J Natl Kidney Found 1995;25(3):492-497.

140. Grolleau F, Gamelin L, Boisdron-Celle M, Lapied B, Pelhate M, Gamelin E. A possible explanation for a neurotoxic effect of the anticancer agent oxaliplatin on neuronal voltage-gated sodium channels. J Neurophysiol 2001;85(5):2293-2297.

141. Robertson WG, Hughes H. Importance of mild hyperoxaluria in the pathogenesis of urolithiasis--new evidence from studies in the Arabian peninsula. Scanning Microsc 1993;7(1):391-401; discussion 401-402.

142. Park H, Eom M, Won Yang J, Geun Han B, Ok Choi S, Kim JS. Peanutinduced acute oxalate nephropathy with acute kidney injury. Kidney Res Clin Pract 2014;33(2):109-111.

143. Sasaki M, Murakami M, Matsuo K, et al. Oxalate nephropathy with a granulomatous lesion due to excessive intake of peanuts. Clin Exp Nephrol 2008;12(4):305-308.

144. Makkapati S, D’Agati VD, Balsam L. "Green Smoothie Cleanse" Causing Acute Oxalate Nephropathy. Am J Kidney Dis 2018;71(2):281-286.

145. Syed F, Mena-Gutierrez A, Ghaffar U. A Case of Iced-Tea Nephropathy. $N$ Engl J Med 2015;372(14):1377-8.

146. Sun Y, Horowitz BL, Servilla KS, et al. Chronic Nephropathy from Dietary Hyperoxaluria: Sustained Improvement of Renal Function after Dietary Intervention. Cureus 2017;9(3):e1105.

147. Bernardino M, Parmar MS. Oxalate nephropathy from cashew nut intake. CMAJ Can Med Assoc J J Assoc Medicale Can 2016;

148. Khneizer G, Al-Taee A, Mallick MS, Bastani B. Chronic dietary oxalate nephropathy after intensive dietary weight loss regimen. J Nephropathol 2017;6(3):126-129.

149. Begbie J. On stomach and nervous disorder, as connected with the oxalic diathesis. Mon J Med Sci 1849;9:943.

150. Bird G. Urinary Deposits: Their Diagnosis, Pathology and Therapeutical Indications [Internet]. Fifth. London, England: John Churchill, New 
Burlington Street; 1857. Available from:

http://collections.nlm.nih.gov/ext/mhlf/101504251/PDF/101504251.pdf

151. Lieske JC, Tremaine WJ, De Simone C, et al. Diet, but not oral probiotics, effectively reduces urinary oxalate excretion and calcium-oxalate supersaturation. Kidney Int 2010;78(11):1178-1185.

152. Schwen ZR, Riley JM, Shilo Y, Averch TD. Dietary management of idiopathic hyperoxaluria and the influence of patient characteristics and compliance. Urology 2013;82(6):1220-1225.

153. Yendt ER, Cohanim M, Peters L. Reduction of urinary oxalate in primary hyperoxaluria by diet. Urolithiasis Clin Basic Res 1981;373-377.

154. Yendt ER, Cohanim M, Peters L. Reduction of urinary oxalate excretion in primary hyperoxaluria by diet. Trans Am Clin Climatol Assoc 1980;91:191201.

155. Susan Costen Owens. Trying Low Oxalates, The Autism Oxalate Project [Internet]. Trying Low Oxalates. 2013;Available from: http://www.lowoxalate.info/

156. Cohen, H, Reid, JB. Tenosynovitis crepitans associated with oxaluria. Liverp Medico-Chir J 1935;43:193-9.

157. Bergstralh EJ, Monico CG, Lieske JC, et al. Transplantation Outcomes in Primary Hyperoxaluria. Am J Transplant Off J Am Soc Transplant Am Soc Transpl Surg 2010;10(11):2493-2501.

158. Ruder H, Otto G, Schutgens RB, et al. Excessive urinary oxalate excretion after combined renal and hepatic transplantation for correction of hyperoxaluria type 1. Eur J Pediatr 1990;150(1):56-58.

159. Tan IL, Zonderland HM, Boevé ER. Oxalosis provoked by extracorporeal shock wave lithotripsy. Lancet Lond Engl 1994;344(8924):757-758.

160. Blackmon JA, Jeffy BG, Malone JC, Knable AL. Oxalosis involving the skin: case report and literature review. Arch Dermatol 2011;147(11):13021305.

161. Haqqani MT. Crystals in brain and meninges in primary hyperoxaluria and oxalosis. J Clin Pathol 1977;30(1):16-18. 
162. Ellis SR, Hulton SA, McKiernan PJ, Ville de Goyet J de, Kelly DA. Combined liver-kidney transplantation for primary hyperoxaluria type 1 in young children. Nephrol Dial Transplant Off Publ Eur Dial Transpl Assoc Eur Ren Assoc 2001;16(2):348-354.

163. Lefaucheur C, Hill GS, Amrein C, et al. Acute Oxalate Nephropathy: A New Etiology for Acute Renal Failure Following Nonrenal Solid Organ Transplantation. Am J Transplant 2006;6(10):2516-2521.

164. Pennington JAT, Spungen J. Bowes \& Church's food values of portions commonly used. Philadelphia, PA: Lippincott, Williams \& Wilkins; 2010.

165. Genuis SJ, Kelln KL. Toxicant exposure and bioaccumulation: a common and potentially reversible cause of cognitive dysfunction and dementia. Behav Neurol 2015;2015:620143.

166. Norton S. When Healthy Isn't: The Risks of High Oxalate Foods. Well $J$ 2015;24(4). 